\title{
Hepatic Natural Killer Cells: Organ-Specific Sentinels of Liver Immune Homeostasis and Physiopathology
}

\author{
Joanna Mikulak ${ }^{1,2}$, Elena Bruni ${ }^{1,2}$, Ferdinando Oriolo ${ }^{1,2}$, Clara Di Vito $^{1}$ and \\ Domenico Mavilio ${ }^{1,2 *}$ \\ ${ }^{1}$ Unit of Clinical and Experimental Immunology, Humanitas Clinical and Research Center, Milan, Italy, ${ }^{2}$ Department of Medical \\ Biotechnologies and Translational Medicine, University of Milan, Milan, Italy
}

The liver is considered a preferential tissue for NK cells residency. In humans, almost $50 \%$ of all intrahepatic lymphocytes are NK cells that are strongly imprinted in a liver-specific manner and show a broad spectrum of cellular heterogeneity. Hepatic NK (he-NK) cells play key roles in tuning liver immune response in both physiological and pathological conditions. Therefore, there is a pressing need to comprehensively characterize human he-NK cells to better understand the related mechanisms regulating their effector-functions within the dynamic balance between immune-tolerance and

OPEN ACCESS

Edited by:

Simona Sivori,

University of Genoa, Italy

Reviewed by:

Rafael Solana,

Universidad de Córdoba, Spain Daniela Pende,

Ospedale San Martino (IRCCS), Italy

*Correspondence:

Domenico Mavilio

domenico.mavilio@unimi.it

Specialty section:

This article was submitted to

NK and Innate Lymphoid Cell Biology,

a section of the journal

Frontiers in Immunology

Received: 01 February 2019

Accepted: 12 April 2019

Published: 30 April 2019

Citation:

Mikulak J, Bruni E, Oriolo F, Di Vito C and Mavilio D (2019) Hepatic Natural Killer Cells: Organ-Specific Sentinels

of Liver Immune Homeostasis and

Physiopathology.

Front. Immunol. 10:946.

doi: 10.3389/fimmu.2019.00946 immune-surveillance. This is of particular relevance in the liver that is the only solid organ whose parenchyma is constantly challenged on daily basis by millions of foreign antigens drained from the gut. Therefore, the present review summarizes our current knowledge on he-NK cells in the light of the latest discoveries in the field of NK cell biology and clinical relevance.

Keywords: tissue immunity, liver, Natural Kill cell, homeostais, homeostasis

\section{INTRODUCTION}

The liver is the largest solid organ in our body receiving every day more than 2,000 liters of blood from dual blood supply. Nearly $80 \%$ of blood derive from the gastrointestinal tract via the portal vein, thus being constantly filled of large amounts of foreign antigens. The remaining $20 \%$ of blood is supplied from the hepatic artery that together with the portal vein terminates into the capillary system of the liver, sinusoids, and leaves liver parenchyma through the hepatic vein.

This large inflow of antigens makes the liver an important immunological organ in which a unique microenvironment shapes both innate and adaptive immune responses in order to maintain a correct balance between immune tolerance and immune activation $(1,2)$. Dysregulation of immune cells in the liver is critical in the pathogenesis of several hepatic diseases, including viral hepatitis, autoimmune disorders and tumors. Liver immune compartment consist in diverse innate populations such as Natural Killer (NK) cells, Natural Killer T (NKT) cells, gamma delta $(\gamma \delta) \mathrm{T}$ cells, and adaptive lymphocytes, such as $\alpha \beta$ T cells and B cells $(1,3)$. On the other hand, liver parenchyma is composed by hepatocytes that represent two-thirds of the total liver cells. Other non-parenchymal cells include liver sinusoidal endothelial cells (LSECs), Kupffer cells (KCs) (i.e., liver-resident macrophages), cholangiocytes, biliary cells, and hepatic stellate cells (HSCs) (3).

Among the immune compartment, hepatic NK (he-NK) cells that contain both liver resident (lr-NK) or either transient through the adult liver conventional NK (cNK) cells, are particularly 
abundant and can account up to $50 \%$ of total hepatic lymphocytes (Figure 1). These innate immune effectors play key roles in order to retain a certain degree of unresponsiveness to "nonself" antigens, while are ready to attack and eliminate the true dangers to the host $(2,4,5)$. Since their discovery in the early 1980 s, NK cells have been valued for rapid recognition and clearance of viral-infected, tumor-transformed and stressed cell targets in the absence of antigen specificity (6). Cytotoxicity and interferon(IFN)- $\gamma$ production represent the main effectorfunctions of mature NK cells and are controlled by a dynamic balance exerted by an array of inhibitory (iNKRs) and activating (aNKRs) receptors differently expressed on the cell surface (7). The dominant mechanism regulating the priming and activation of resting NK cells is based on the engagement of several iNKRs that bind several alleles of the major histocompatibility complex class I (MHC-I) expressed on the surface of autologous cells. This recognition spares from NK cell killing all "self" targets, thus ensuring a perfect $\mathrm{NK}$ cell tolerance toward our own cells. These iNKRs include inhibitory Killer Ig-like receptors (iKIRs) that recognize classical MHC-I alleles and the C-type lectin like receptor NKG2A that forms a heterodimer with the CD94 molecule (CD94/NKG2A), binding HLA-E, a nonclassical MHC-I complex $(8,9)$. Either the decreased expression or the absence of MHC-I on target cells triggers NK cell killing, a phenomenon known as "missing-self hypothesis," via the employment of aNKRs that, in turn, bind their putative ligands expressed on viral-infected, malignant or stressed cells. The Natural Cytotoxicity Receptors (NCRs) NKp30, NKp46 and NKp44, the C-type lectin receptors NKG2D and CD94/NKG2C heterodimer, DNAM-1, SLAM family receptors such as 2B4, and activating KIRs (aKIRs) are the main aNKRs inducing NK cell cytotoxicity $(7,10,11)$.

Under homeostatic conditions, human circulating $\mathrm{cNK}$ cells represent about $5-15 \%$ of circulating lymphocytes and are subdivided into two main subsets defined on the basis of their differential expression of CD56 and CD16, namely CD $56^{\text {bright }} / \mathrm{CD} 16^{\text {neg }}\left(\mathrm{CD} 56^{\text {bright }}\right)$ and $\mathrm{CD} 56^{\mathrm{dim}} / \mathrm{CD} 16^{\text {pos }}$ $\left(\mathrm{CD} 56^{\mathrm{dim}}\right) \mathrm{NK}$ cells $(12)$. It is largely accepted that CD56 $6^{\text {bright }}$ NK cells are the precursors of the more mature CD56 $6^{\mathrm{dim}}$ NK cells, however, the developmental relationship between the different types of human NK subsets has not been finally clarified $(13,14)$. In this context, a recent study proposes for two CD56 $6^{\text {bright }}$ and CD56 ${ }^{\mathrm{dim}} \mathrm{NK}$ cell subsets distinct ontologies (14). The low amounts of intracellular cytotoxic granules (i.e., Perforin and Granzymes A-B) parallel the poor cytotoxic potential of CD56 $6^{\text {bright }} \mathrm{NK}$ cells that are also unable to perform the antibody (Ab)-dependent cellular cytotoxicity (ADCC) in line with their undetectable expression of CD16 (12). On the other hand, this latter subpopulation exerts important regulatory functions through secretion of chemokines and pro-inflammatory cytokines [i.e., IFN- $\gamma$, Tumor Necrosis Factor(TNF)- $\alpha$ ] in response to different stimuli [i.e., interleukin (IL)-1 $\beta$, IL-2, IL-12, IL-15, and/or IL-18] delivered by surrounding cells at tissue sites [i.e., macrophages, dendritic cells (DCs), and T lymphocytes] $(6,15,16)$. CD56 bright $\mathrm{NK}$ cells likely give rise to terminally differentiated CD56 ${ }^{\mathrm{dim}} \mathrm{NK}$ cells as they represent the largest population in blood (up to
90\%), mostly express lower levels of NKp46 and CD94/NKG2A and higher amounts of iKIRs and CD94/NKG2C heterodimer (17). This population exerts both high cytotoxicity and ADCC given its high constitutive expression of CD16 in response to activation by IL-12, IL-15, and IL-18 (18). Moreover, it has been reported that $\mathrm{CD} 56^{\mathrm{dim}} \mathrm{NK}$ cells can also rapidly produce IFN- $\gamma$ in response to stimulation with IL-2 and/or IL-15 (19). Hence, CD56 ${ }^{\text {bright }}$ and CD56 ${ }^{\text {dim }}$ NK cell subsets fulfill distinct roles in immunity, with the first one serving more as immune-modulator and the second population acting mainly as cytotoxic effector. An additional NK cell subset identified on the basis of CD56 and CD16 surface expression is represented by anergic $C D 56^{\text {neg }} / \mathrm{CD} 16^{\text {pos }}\left(\mathrm{CD} 56^{\text {neg }}\right)$ cells that are present at very low frequency under physiologic conditions, while pathologically expanded during the course of several disorders, such as viral infections and autoimmune diseases $(20,21)$. More recently, an unconventional population of $\mathrm{CD} 56^{\mathrm{dim}} / \mathrm{CD} 16^{\text {neg }}$ (unCD56 ${ }^{\mathrm{dim}}$ ) NK cells has been described. This latter subset can exert potent cytotoxicity and is extremely rare in healthy donors, while representing the main $\mathrm{cNK}$ cell population in the first weeks after haploidentical hematopoietic stem cell transplants (haplo-HSCT). This high frequency of unCD56 ${ }^{\text {dim }}$ NK cells in aplastic patients affected by hematologic malignancies and receiving haplo-HSCT suggests novel pathways of NK cell ontogenesis and differentiation that are currently being investigated $(22,23)$.

The distribution of NK cell subsets in human tissues is very peculiar and differs from what we observe in peripheral blood. Notably, CD56 ${ }^{\mathrm{dim}}$ NK cells are found in high amounts in bone marrow, lung, spleen, subcutaneous adipose tissue and breast tissue. Instead, CD56 ${ }^{\text {bright }} \mathrm{NK}$ cells are present at high frequency in lymph nodes, gut, liver, uterus, visceral adipose tissue, adrenal gland and kidney $(24,25)$. Hence, other than the phenotypic and functional diversities of these latter two subsets in peripheral blood, the spectrum of human NK cell populations in tissues is much broader and likely depends on specific imprinting given by local microenvironments and by the chronic exposure to foreign antigens/inflammatory stimuli.

Here, we review our current knowledge in regard to he-NK cells with a particular focus on the breadth and generation of heNK cell heterogeneity, under both homeostatic conditions and during the course of liver diseases.

\section{HETEROGENEITY OF LIVER RESIDENT NK CELLS}

The liver is populated by both transient cNK cell subsets and lrNK cells that are phenotypically and functionally distinguished (Figure 1). The first identification of tissue resident NK cells occurred in murine livers and rapidly expanded in other tissues (26). Lr-NK cells soon displayed heterogenous phenotypic profiles in different species with unique anatomical identities that reflect the impact of this peculiar tissue-niche in generating either cytotoxic or tolerogenic lymphocytes.

Murine lr-NK cells carry a CD $49 \mathrm{a}^{\text {pos }} / \mathrm{DX} 5^{\text {neg }}$ phenotype that differs from $C D 49 a^{\text {neg }} / \mathrm{DX} 5^{\text {pos }} \mathrm{cNK}$ cells in mouse $(27,28)$. It 


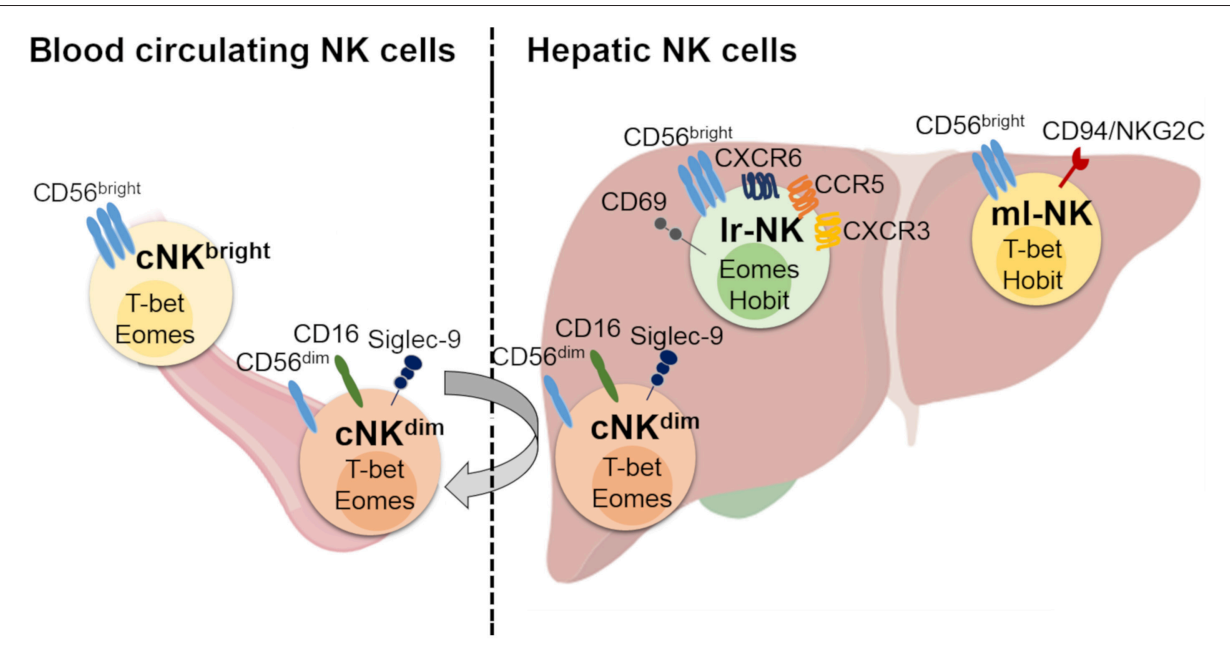

FIGURE 1 | Human hepatic and conventional NK cell subsets, distribution, and phenotype. Human blood circulating conventional NK (cNK) cells contain two main subsets: $\mathrm{CD}_{5} 6^{\mathrm{dim}}$ ( $\mathrm{cNK}^{\mathrm{dim}}$ ) and CD56 bright (cNK ${ }^{\text {bright }}$ ) cells. Human hepatic NK (he-NK) cell compartment contains: liver resident NK (II-NK) cells, memory-like NK (ml-NK) cells and transient conventional NK ( $\mathrm{CNK}$ ) cells mainly represented by recirculating $\mathrm{CNK}^{\text {dim }}$ cells through the liver blood system (gray arrow). Lr-NK and ml-NK cell subsets show transcriptional and phenotypic differences compared to the conventional cNK cell subsets.

is still unclear how the development and differentiation of lrNK cells is regulated, but this latter subset seems to be more terminally differentiated as it lacks or has decreased expression of CD11b, Ly49, CD43, and KLRG1 (i.e., surface markers present on mature cells) compared to murine cNK cells (27). Several experimental findings indicated that $\mathrm{lr}-\mathrm{NK}$ and $\mathrm{cNK}$ cells likely develop from separated innate lymphoid cell (ILC) lineages (29). Moreover, a common ILC progenitor subset able to differentiate in lr-NK cells but not in cNK cells has been described (30). Indeed, lr-NK and cNK cells rely on different transcriptional factors for their development, since the presence of T-bet deficiency in mice is associated with the depletion of $1 r-\mathrm{NK}$ cells, while Eomes is critical for the maintenance of cNK cell homeostasis (Table 1) $(31,32)$. More recently, the new transcription factors Hobit and the aryl hydrocarbon receptor (AhR) have been reported to induce the development of different tissue-resident NK cells, including $\operatorname{lr}-\mathrm{NK}(33,34)$.

Human lr-NK cells were first described in 1976 and were originally called "pit cells." Only later, they were defined as highly cytotoxic NK cells resident in the hepatic sinusoids (35, $43,44)$. Differently from murine and their human counterparts in peripheral blood, CD56 ${ }^{\text {dim }}$ and CD56 bright $\mathrm{NK}$ cells are present at similar frequencies in liver and the latter subset likely corresponds to the murine $\mathrm{CD} 49 \mathrm{a}^{\text {pos }} / \mathrm{DX} 5^{\text {neg }} \mathrm{lr}-\mathrm{NK}$ cells, as they both share the same transcriptional factor $\mathrm{T}$ bet and are negative for Eomes (Table 1) (28). However, CD $49 \mathrm{a}^{\text {pos }} / \mathrm{CD} 56^{\text {bright }}$ lymphocytes account for only $3 \%$ of all humans he-NK cells and do account for all CD56 bright $1 r-$ NK cells. In this regard, it is well known that several murine NK cell markers are not phylogenetically conserved in their human counterparts and this largely explains the absence of a phenotypic match between murine and human lr-NK cells. Only recently, the phenotype of human CD56 bright $\mathrm{lr}-\mathrm{NK}$ cells has been better characterized by disclosing their constitutive expression of the chemokine receptors CXCR6 and CCR5 and of the tissue-residency marker $\operatorname{CD} 69(28,45,46)$. As a matter of fact, these 3 surface markers are absent on CD56 ${ }^{\mathrm{dim}}$ heNK cells. Hence, the CD $56^{\text {bright }} /$ CCR $^{\text {pos }} /$ CXCR6 $^{\text {pos }} /$ CD69 9 pos phenotype identifies human lr-NK cells that also appear to be more heterogeneous in their development pathways compared to murine counterparts as they express high levels of Eomes transcripts rather than T-bet $(36,45,46)$. Indeed, only those $3 \%$ of human $\mathrm{CD} 49 \mathrm{a}^{\text {pos }} / \mathrm{CD} 56^{\text {bright }}$ lr-NK cells resulted positive for T-bet, while the transcription factor Hobit was found positive on all CD56 ${ }^{\text {bright }}$ lr-NK cells $(28,37)$.

Very little is known about the mechanism(s) regulating both recruitment and retention of NK cells in the liver. Within the hepatic microenvironment, NK cell interactions with LSECs certainly play a key role, as the masking of CD2, CD11a, CD18, and CD54 (ICAM-1) with neutralizing monoclonal Abs (mAbs) block their recruitment to the liver (38). Moreover, the constitutive high surface levels of CXCR3, CXCR6, and CCR5 on lr-NK cells are important in the retention of these hepatic lymphocytes. Indeed, the engagement of these chemokine receptors following the binding with their cognate ligands (i.e., CCL3, CCL5 and CXCL16, respectively) expressed by cholangiocytes, LSECs, hepatocytes, and KCs, is associated with liver homing $(45,47)$. Sinusoidal endothelial cells also express VAP-1 that, in turn, binds Siglec- 9 expressed on cNK cells, thus mediating their migration to the liver $(47,48)$. This latter pathway seems a mechanism restricted to hepatic trafficking, since VAP$1^{\text {pos }}$ cNK cells do not express L-selectin (CD62L) and CCR7 receptor required for homing in secondary lymphoid tissues (27).

Another important question is whether he-NK cells stably reside in the liver or recirculate through liver sinusoids. Experimental evidence obtained from human transplanted liver revealed that Eomes ${ }^{\text {high }}$ lr-NK cells can persist for decades, thus further supporting the idea that these cells represent a long-lived 
TABLE 1 | Comparison of NK cell subsets in humans and mice.

\begin{tabular}{|c|c|c|c|c|c|}
\hline Species & Subset & Phenotype & Precursors & $\begin{array}{l}\text { Transcription } \\
\text { factors }\end{array}$ & References \\
\hline Mouse & $\mathrm{cNK}$ & $C D 49 a^{\text {neg }} D \times 5^{\text {pos }}$ & Lin $^{\text {neg }} C D 27^{\text {pos }} C D 107^{\text {neg }} C D 244^{\text {pos }} C D 122^{\text {pos }} \mid L 7$ Raneg & Eomes & $(28-33)$ \\
\hline Mouse & $|r-N K / m|-\mid r-N K$ & CD49apos $D \times 5^{\text {neg }}$ & 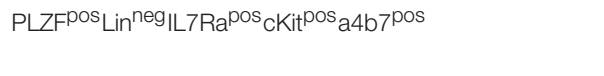 & $\begin{array}{l}\text { T-bet, PLZF, } \\
\text { Hobit, AhR }\end{array}$ & $(28-35)$ \\
\hline Human & $\mathrm{cNK}^{\mathrm{dim}}$ & CD56 ${ }^{\operatorname{dim}}$ CD16 ${ }^{\text {pos }}$ & $\mathrm{CD}_{56}^{\text {bright }} \mathrm{CD} 94^{\text {pos }} \mathrm{NKp} 80^{\text {pos }} \mathrm{CD} 16^{\text {neg }} \mathrm{CD} 57^{\text {neg }}$ & T-bet, Eomes & $(13,14)$ \\
\hline Human & cNK bright & CD56 ${ }^{\text {bright }}$ CD16 ${ }^{\text {neg }}$ & $\operatorname{Lin}^{\text {neg }} C D 34^{\text {neg }} C D 117^{\text {pos }} C D 94^{\text {neg }} C D 16^{\text {neg }}$ & T-bet, Eomes & $(13,14)$ \\
\hline Human & $\begin{array}{l}\text { Ir-NK }{ }^{\text {bright }} \\
\text { ml-NK }{ }^{\text {bright }}\end{array}$ & $\begin{array}{l}\text { CCR5 }{ }^{\text {pos }} \text { CXCR6 }{ }^{\text {pos }} \text { CD69pos } \\
\text { CXCR6 }{ }^{\text {pos }} \text { CD94/NKG2Cpos }\end{array}$ & $\begin{array}{l}\text { CD56 }{ }^{\text {bright }} \text { Eomes }{ }^{\text {low }} \mathrm{CNK} \text { bright } \\
\text { Ir-CD49a }{ }^{\text {pos }} \text { CD56 }{ }^{\text {bright }}\end{array}$ & $\begin{array}{l}\text { Eomeshigh, } \\
\text { Hobit T-bet, } \\
\text { Hobit }\end{array}$ & $\begin{array}{c}(28,29,36- \\
42)\end{array}$ \\
\hline
\end{tabular}

tissue-resident subset (49). In addition, CD56 ${ }^{\text {bright }} /$ Eomes $^{\text {low }}$ cNK cells recruited to the liver have the potential to become CD56 $6^{\text {bright }} /$ Eomes ${ }^{\text {high }}$ NK cells. This last piece of data suggests that cNK cells can also represent precursors of their liver-resident counterparts, although the associated mechanisms involved in this process have not yet been disclosed (49). Interestingly, the administration of an anti- $\alpha 4 \beta 1$ and $-\alpha 4 \beta 7$ integrins $\mathrm{mAb}$ (i.e., natalizumab) in patients with multiple sclerosis is associated with an remarkable increased frequency of NK cells in peripheral blood, thus indicating that they can migrate across the tissue endothelial barriers including the hepatic ones $(39,50)$. However, it is important to highlight that he-CD56 ${ }^{\mathrm{dim}} \mathrm{NK}$ cells are transcriptionally and phenotypically similar to their circuiting counterparts and this evidence indicates that they likely recirculate through the liver blood system without being retained in the organ. This is not the case for lr-CD56 bright NK cells that are also transcriptionally different from their homologs in the peripheral blood (45).

The liver is also home of peculiar and newly identified lrNK cells endowed with unique adaptive traits and showing hapten-specificity $(51,52)$. The phenotype of these so-called "memory like" NK (ml-NK) cells in mice is CD $49 \mathrm{a}^{\text {pos }} / \mathrm{DX} 5^{\text {neg }}$ and matches with murine lr-NK cells $(51,52)$. It has been also shown that CXCR6 $^{\text {pos }}$ he-NK cells can retain an unconventional immunologic memory versus viral antigens including inactivated vesicular stomatitis virus (VSV), human immunodeficiency virus (HIV) and influenza $(53,54)$. Most of the studies characterizing human ml-NK cells focused their investigation on cytomegalovirus (HCMV) infection, that induces the expansion of "specific" CD94/NKG2C ${ }^{\text {pos }} \mathrm{NK}$ cells able to produce a higher amount of IFN- $\gamma$ when these "adaptive" NK cells are rechallenged with the same virus $(40,41,55)$. Interestingly, it has been reported that the small subset of CD $49 \mathrm{a}^{\text {pos }} / \mathrm{CD} 56^{\text {bright }}$ lr-NK cells is characterized by a clonal-expansion of $\mathrm{NK}$ cells expressing CD94/NKG2C heterodimer (28). However, the existence of a specific viral-antigen recognized by a given NKRs expressed on human ml-NK cells is still being debated and never formally demonstrated. This is indeed a very hot research topic in the field of $\mathrm{NK}$ cell homeostasis that requires further experimental evidence and investigations.

Lr-NK cells are characterized by different features and can kill different targets as well as secrete cytokines. They have higher intracellular amounts of lytic granules (i.e., Granzymes and Perforin) and stronger cytotoxic potentials compared to their circulating counterparts $(2,42,56)$. In particular, lrNK cells are characterized by higher constitutive expression of TRAIL and FasL compared to cNK cells, thus suggesting that the tissue resident subset employs different mechanisms to eliminate targets (i.e., apoptosis) (57). Moreover, both cNK cells and lr-NK cells are able to secrete large amount of IFN$\gamma$, but the latter population is much more efficient in the production of TNF- $\alpha$ and Granulocyte-macrophage colonystimulating factor (GM-CSF), and in case of murine lr-NK cells IL-2, all key players in inflammatory responses at tissue sites $(31,32,57)$.

The need of keeping an optimal degree of immunetolerance vs. foreign antigens while ensuring a correct immunesurveillance against potential threats (i.e., infections, tumors, aberrant inflammation, and autoimmunity) certainly explains the particularly high level of heterogeneity and complexity of he-NK cells. Indeed, these features are peculiar of the liver microenvironment that is able to induce the non-conventional "long-lived" and "memory like" innate immune effectors also within NK cell compartment.

\section{NK CELLS IN LIVER TOLERANCE AND HOMEOSTASIS}

Human liver developed a high degree of immune tolerance as demonstrated by the clinical evidence indicating that liver allografts are less likely to be rejected than other transplanted organs (58). Several actors play different and fundamental roles in the maintenance of liver tolerogenic NK cells (Figure 2). KCs produce high doses of IL-10 which was observed to be critical in the control of mice intrahepatic NK cell-mediated alloreactivity (59). Indeed, an impaired ability of liver macrophages to produce this anti-inflammatory cytokine boost the IFN- $\gamma$-dependent priming of he-NK cells in response to double strand RNA exposure $(60,61)$. Moreover, the interplay between cNK cells co-cultured with human hepatic cells, and DCs induces the expansion of tolerogenic $\mathrm{T}$ cells (Tregs) via the engagement of CD94/NKG2A, which is a mechanism able to trigger the production of both transforming growth factor- $\beta$ (TGF- $\beta$ ) and IL-10 $(62,63)$. Interestingly, in vitro stimulation of human cNK cells with apoptotic cells develops tolerance in these innate 


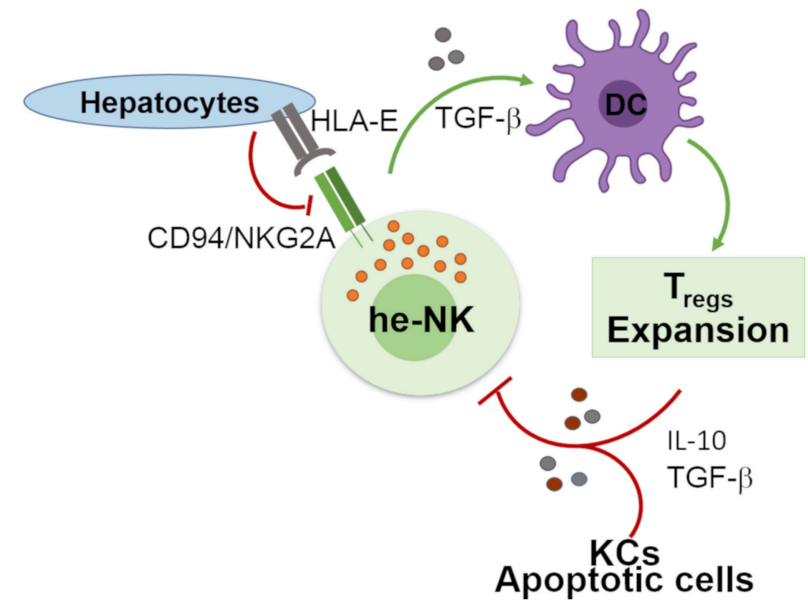

FIGURE 2 | Involvement of he-NK cells in the maintenance of hepatic tolerance and homeostasis. NK cells promote hepatic tolerance by interplaying with hepatocytes via CD94/NKG2A that in a TGF- $\beta$-mediated manner modulate DCs that further prompt expansion of tolerogenic CD4pos CD25pos Treg cells. On the other hand, Treg cells along with hepatic KCs and apoptotic cells contribute to the production of immunosuppressive factors IL-10 and

TGF- $\beta$ that can induce tolerogenic he-NK cells. Green arrows show stimulatory connection and red lines inhibition.

effector cells via the secretion of TGF- $\beta$ that, in turn, suppresses their autocrine IFN- $\gamma$ production (64).

Different studies demonstrated that he-NK cells are also important in regulating the unique capacity of liver to regenerate itself after tissue damage $(65,66)$. In this regard, in the in vivo model interaction of cNK cells with surrounding different liverresident cells (i.e., KCs, fibroblast, and stem cells) induces the secretion of growth factors, hormones, cytokines, and chemokines able to induce the proliferation/regeneration of hepatic tissue (67). In particular, the activation of he-NK cells is associated with a de novo production of CXCL7, CXCL2, CCL5 and IL- 8 that, in turn, can recruit and differentiate mesenchymal stem cells substantially contributing to the so-called "restitutio ad integrum" of this organ (65). This is a process that needs to be finely tuned and regulated since paradoxically over-stimulation of mouse he-NK cells can inhibit, rather than promoting, liver regeneration through the aberrant signaling pathway exerted by IFN- $\gamma$ on those factors (i.e., STAT1, IRF-1, and p21cip1/waf1) regulating hepatocyte proliferation $(68,69)$. This is the case of in vivo activation with high doses of the immuno-stimulant Polyinosinic:polycytidylic acid (Poly I:C) (70).

\section{NK CELLS IN THE PATHOGENESIS OF AUTOIMMUNE LIVER DISEASES}

Those mechanisms that make it possible for the liver to develop immunologic tolerance also expose this organ to the onset of immunological diseases. In this context, the presence of dysfunctional he-NK cells can actively contribute to the breach of immunological tolerance and in the appearance of autoimmuneliver diseases including autoimmune hepatitis $(\mathrm{AIH})$, primary biliary cholangitis (PBC), and primary sclerosing cholangitis (PSC) $(2,71)$.

Although T cells have been reported to play a prominent role in the pathogenesis of AIH, several lines of evidence showed that also autoreactive he-NK cells are expanded in this autoimmune liver disorder (72). Indeed, the in vivo administration of Poly I:C in mice induces the onset of AIH in which activated intrahepatic NK cells actively contribute to liver damage (73). Additionally, the low frequency of the inhibitory KIR/KIRligand combinations KIR3DL1/HLA-Bw4 and KIR2DL3/HLA$\mathrm{C} 1$ coupled to the high frequency of the HLA-C2 high affinity ligands for KIR2DS1 may contribute to unwanted NK cell autoreactivity in AIH (74). The expansion of aberrant NK cells able to kill autologous cholangiocytes represents also one of the pathogenic mechanisms present during the course of PBC $(75,76)$. Indeed, the frequency of he-CD $56^{\mathrm{dim}} \mathrm{NK}$ cells in $\mathrm{PBC}$ is higher compared to that of healthy livers. However, it is still unclear whether the expansion of autoreactive heNK cells targeting autologous biliary epithelial cells is directly associated with breach of liver immune tolerance or if this is a secondary event linked to the high degrees of immune activation and inflammation present in PBC (77). Another mechanism employed by cNK cells to lyse "self" cholangiocytes relies on the engagement of TRAIL pathway. As a matter of fact, the downstream death signal delivered by TRAIL receptor 5 is higher in $\mathrm{PBC}$ patients and induces cholestatic liver injury $(78,79)$. Another study also reported a protective role of intrahepatic NK cells in PBC patients, as the presence of low $\mathrm{NK}$ cell/cholangiocytes ratio is associated with higher IFN- $\gamma$ production. This can induce or increases the expression of MHCI and -II on cholangiocytes that are, in turn, spared from the lysis exerted by autoreactive NK cells. This latter protective mechanism is particularly relevant in the initial stages of PBC, since it can slow its progression to liver failure (80).

Among the three main liver autoimmune diseases, PSC represents the one whose pathogenesis is still largely unknown. However, the presence of certain HLA alleles or genetic variants of the NKG2D ligand MIC-A had been associated with higher risks of developing $\mathrm{PBC}$. Indeed, both these molecular patterns regulate NK cell recognition of cholangiocytes (81). Similar to $\mathrm{AIH}$ and $\mathrm{PBC}$, an increase of he-NK cell frequency was detected in PSC patients $(82,83)$. The most prominent current working hypothesis postulates that, similar to $\mathrm{PBC}$, the engagement of TRAIL could induce the he-NK-mediated destruction of cholangiocytes in PSC patients $(42,79)$. Finally, another study reported that lr-NK cells from PSC patients are impaired in their cytotoxicity due to the high levels of local TNF- $\alpha$ production (84). Taken together, these contradictory data and speculations in regard to PSC pathogenesis reflect our general lack of knowledge in regard to the mechanistic roles and clinical impact of he-NK cells in liver autoimmune diseases.

\section{NK CELLS IN LIVER CANCER}

Hepatocellular carcinoma (HCC) is the most common leading cause of liver-cancer related death worldwide (85). Among 
the main predisposing risk factors of HCC, there are chronic viral infections by hepatitis B virus (HBV) and hepatitis C virus $(\mathrm{HCV})$, alcohol related cirrhosis and non-alcoholic steatohepatitis (86). The liver is also the first site of colorectal cancer (CRC) metastatic dissemination (87). NK cells had been first discovered due to their ability to kill tumor-transformed cells (i.e., immune surveillance) and are able to provide protection in hematological malignancies, solid primary cancers and metastatic lesions $(88,89)$. This important feature is also valid for HCC as human cNK cells were shown to be highly cytotoxic against HepG2 hepatocellular carcinoma cells (2, 42, 56). Moreover, it has been reported that higher numbers of total tumor infiltrating $\mathrm{CD} 56^{\mathrm{pos}}$ he-NK cells predict a better outcome for HCC in terms of patient overall survival (OS) (9092). Other retrospective studies showed that high frequencies of the specific intra-tumor NK cell subsets slow the progression of liver cancer, as demonstrated for human NKp46 $6^{\text {pos }}$ he-NK cells in CRC metastatic disease and for CD11b $b^{\text {neg }} / C D 27^{\text {neg }}$ heNK cells in HCC $(93,94)$. In addition, the selective engagement of NKG2D in both mice and human enhances NK cell antitumor activity against HCC since the transcriptional modulation or the interferon-induced expression of this aNKR boosts he-NK cell cytotoxicity and blocks tumor growth $(95,96)$. This potent anti-tumor NK cell effector-function against HCC seems to be more effective in the early stages of the tumor and decreases as soon as the disease progresses (Figure 3). Indeed, lower frequencies of anergic/dysfunctional CD56 ${ }^{\mathrm{dim}}$ and CD56 ${ }^{\text {bright }}$ NK cells, characterizes end-stages HCC patients both in peripheral blood and at a tumor site, a phenomenon that is also associated with a parallel expansion of $\mathrm{CD} 4{ }^{\mathrm{pos}} / \mathrm{CD} 25^{\text {pos }}$ Tregs and increased secretion of IL-10 $(92,97,98)$. Several mechanisms have been proposed to explain, at least in part, the functional impairments of NK cells in advanced HCC. These include the increased expression on tumor infiltrating NK cell surface of inhibitory checkpoints [i.e., programmed cell death protein (PD1) and NKG2A] as well as the higher surface levels of PD-1 ligands (PD-1Ls) and MHC-I on malignant cells. Both strategies simultaneously employed by HCC both on immune-effectors and targets have the same aim of evading human NK cell immunesurveillance, thus sparing tumor cells from NK cell killing (99102). It has been also reported that in advanced HCC patients he-NK cells express a specific inhibitory NKp30 splice variant (Ih-NKp30), thus resulting in a deficiency of NKp30-mediated NK cell activation and function. Interestingly, the soluble form of NKp30 ligand (NKp30L) B7-H6 is increased in late stages of HCC (103). Another mechanism contributing to cNK cell impairment in HCC patients relies on their aberrant interactions with tumor infiltrating macrophages, inducing a rapid NK cell exhaustion both via the engagement of CD48/2B4 and NKp30 pathways $(98,104,105)$. Additionally, several alterations in the cytokine milieu of neoplastic HCC tissue can influence cNK cell cytotoxicity and cytokine production. These include soluble immune-modulators such as TGF- $\beta$, prostaglandin E2 (PGE2) or indoleamine 2,3-dioxygenase (IDO) (105-107). More recently, it has been reported that IL-1R8 (TIR-8) can serve as another important checkpoint able to inhibit anti-tumor NK cell effectorfunctions in liver cancer murine models. Indeed, its blockade unleashes NK cell-mediated resistance to hepatic carcinogenesis and liver metastasis of CRC (108). Moreover, using a mouse model of cholangiocarcinoma (CCA), it has been demonstrated that adoptive NK cell transfer limits tumor growth and improves the prognosis of this aggressive liver cancer, although the related mechanisms associated to NK cell control of CCA have not yet been elucidated (109).

\section{LIVER NK CELLS AND VIRAL INFECTION}

HCV and HBV infections represent the main two infectious diseases inducing liver inflammation and failure (110). Controversial data are available regarding the immune status of he-NK cells in acute and chronic liver viral infections (Figure 3).

In acute HCV infection, he-NK cells show an increased expression of NKp46 and a high ability to degranulate and to produce IFN- $\gamma$ following a strong activation by IFN- $\alpha / \beta$ and other cytokines (i.e., IL-12, IL-15, IL-18) (111, 112). Although intrahepatic CD56 $6^{\text {bright }} / \mathrm{NKp} 46^{\text {high }}$ he-NK cells contribute to a better control of HCV replication, their presence at high frequency is also associated with increased degrees of liver necrosis and fibrosis following acute infection (113). Interestingly, the livers of those patients experiencing self-limiting HCV-1 infection were not enriched of CD56 $6^{\text {bright }} / \mathrm{NKp} 46^{\text {high }}$ he-NK cells, but of NK cells are highly positive for CD57 and KIRs. These findings suggest that terminally-differentiated NK cells can better control HCV infection (114).

In the context of HBV infection, early cNK cell responses contribute to the initial control of infection and to the development of an efficient adaptive immune response through the secretion of IFN- $\gamma$, TNF- $\alpha$, GM-CSF, and TGF- $\beta$ able to inhibit viral replication or to induce the killing of infected cells (115-117). In this context, acute HBV infected patients showed an expansion of $\mathrm{CD} 56^{\text {bright }} \mathrm{cNK}$ subset, but reduced frequencies of CD56 $6^{\text {dim }}$ NK cells. Notably, the inflamed lobular necrotic areas of HCV-infected livers from the same individuals were surrounded by NKp46 $6^{\text {pos }} \mathrm{NK}$ cells (118). In vivo experimental studies also confirmed the presence of a strong activation of he-NK cells in response to acute HBV infection, a mechanism that limits viral replication. However, in these animal models the $\mathrm{HCV}$-mediated priming of NK cells was not able to induce an antigen-specific $\mathrm{T}$ cells response (119-121).

When both HBV and HCV enter into their chronic stages, the frequencies of cNK cells remarkably decrease together with their ability of producing pro-inflammatory cytokines, such as IFN- $\gamma$ and TNF- $\alpha$ (122-125). Although, he-NK cells maintain their cytotoxic potential in chronic HBV via the upregulation of TRAIL $(126,127)$, however, they pathologically contribute to eliminate autologous $\mathrm{HBV}$-specific $\mathrm{CD} 8^{\text {pos }} \mathrm{T}$ cells expressing high levels of death receptor for TRAIL. Hence, this NK cell-mediated depletion of antigen-specific $C D 8^{\text {pos }} \mathrm{T}$ cells impairs adaptive antiviral immunity in chronic HBVinfected patients and contributes to viral persistence (128-130). Moreover, persistent viral infections have a remarkable impact on the cNK cell receptor repertoire and profoundly affect their 


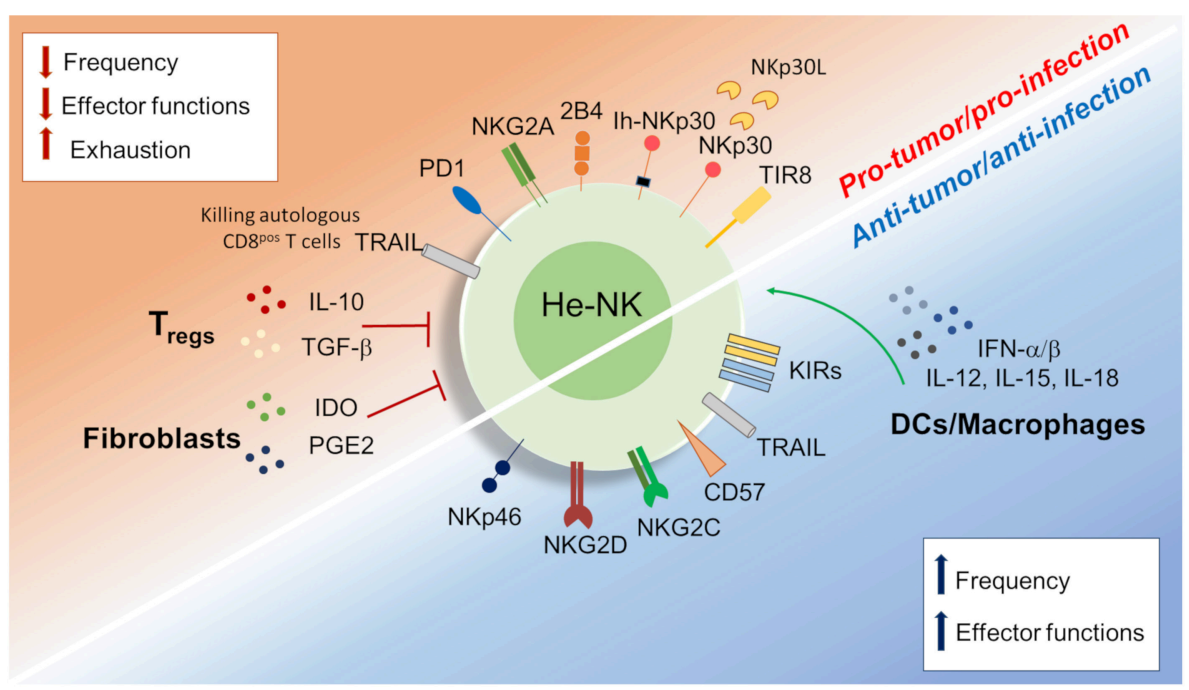

FIGURE 3 | Dichotomy in the he-NK cell response in tumor and viral infection. Different soluble factors and cell surface receptors contribute to positive or either negative he-NK cell response in both tumor and/or viral infection. Increased (vertical blue arrows) frequency and effector-functions of he-NK cells were observed in early tumor and acute viral response. On the other hand, NK cell dysfunction (vertical red arrows) in late tumor or chronic infection results with lower NK cells frequency, effector function inhibition and cell exhaustion. Arched green arrows show stimulatory connection and red lines inhibition.

effector-functions. Indeed, chronic exposure to HBV induces TGF- $\beta$ production that, in turn, reduces the expression of NKG2D and 2B4, and their respectively, intracellular adaptor proteins DAP10 and SAP, thus further hampering their ability to eliminate viral infected cells (131). However, whether this immunosuppressive mechanism plays a role in shaping he-NK cells need to be further consolidated.

\section{HEPATIC NK CELLS AS POTENTIAL THERAPEUTIC TARGETS}

The possibility of tuning NK cell effector-functions represents an important therapeutic strategy for the treatment of several liver disorders, as demonstrated for infections and other malignancies (112, 113). Among the main methodological approaches developed in this context, there are protocols administering in vivo compounds targeting NK cell activation. Indeed, the use of several cytokines that can easily reach and activate liver endogenous NK cells has been extensively tested in several clinical and experimental trials. IL-12 and IL18 have been shown to effectively inhibit liver carcinogenesis by boosting NK cell anti-tumor functions (132). Therapies with interferons showed anti-viral, anti-fibrotic and anti-tumor NK cell-mediated clinical outcomes $(96,133)$. Two cytokines widely adopted to enhance NK cell cytotoxicity are IL-2 and IL-15 (134, 135). In particular, IL-15 can rescue the antitumor activities of intrahepatic NK cells purified from HCC patients (136). Interestingly, the use of recombinant/modified IL-2 and IL-15 activates both NK and CD8 ${ }^{\text {pos }} \mathrm{T}$ cells without stimulating Tregs and these cytokines are currently being tested also against hematological cancers (137-139). Agonists for several aNKRs expressed on lr-NK cells, such as NKG2D and NCRs, also represent a potential clinical therapeutic strategy. Moreover, the expression of NKRs can be also modulated at the transcriptional level. In this regard, the miR-182 has been shown to increase NK cells cytotoxicity in HCC patients by regulating the expression of NKG2D and NKG2A (95).

In a new era of cancer immunotherapy, several inhibitory checkpoints have been targeted also on NK cells through the development of blocking mAbs unleashing their antitumor effector-functions (13). In particular, anti-KIR mAbs are currently being tested in different hematological cancers alone or in combination with other treatments (140). Another important NK cell inhibitory checkpoint is anti-NKG2A, whose masking $\mathrm{mAb}$ is currently being tested in several solid tumors and hematologic diseases $(23,141-144)$. More recently, it has been also reported that NK cells can express PD-1 thus paving the ground in the future to target NK cells also with mAbs blocking PD-1/PD-L1 interactions (145). Further clinical trials are required to investigate the efficacy of these compounds in liver cancers.

Adoptive NK cell transfer therapies have been first introduced to improve the clinical outcome of patients affected by hematologic malignancies and undergone allogeneic hematopoietic stem cell transplantation (allo-HSCT) $(146,147)$. The great clinical outcome of this strategy in allo-HSCT together with newly available technologies made it possible to develop new protocols of adoptive NK cell therapies to treat both hematologic malignancies and solid tumor (148-151). More recently, the possibility of engineering NK cells with different technological approaches such as the so-called bi- and tri-specific killer engagers (BiKEs and TriKEs) (152) or chimeric antigen 
receptors (CARs) (153) improved both tumor-specificity and the ability of NK cells to reach/infiltrate tumor tissues. Very little is known about the efficacies of adoptive NK cell transfer therapies in liver cancers, a gap that needs to be filled by new experimental and clinical trials.

\section{CONCLUDING REMARKS}

Despite a great number of studies that have been focusing on elucidating the role of he-NK cells in liver physiology and physiopathology, several questions still remain unanswered. In particular, given the high heterogeneity of NK cells in liver, further studies are needed to investigate their specific role in both homeostatic and pathological conditions. Indeed, understanding this high degree of diversity will likely explain the several and often opposite functions of he-NK cells. These include the different capacities of he-NK cells either to reside in the liver or to recirculate through this organ without being retained

\section{REFERENCES}

1. Crispe IN. The liver as a lymphoid organ. Annu Rev Immunol. (2009) 27:147-63. doi: 10.1146/annurev.immunol.021908.132629

2. Hudspeth K, Pontarini E, Tentorio P, Cimino M, Donadon M, Torzilli G, et al. The role of natural killer cells in autoimmune liver disease: a comprehensive review. J Autoimmun. (2013) 46:55-65. doi: 10.1016/j.jaut.2013.07.003

3. Jenne CN, Kubes, P. Immune surveillance by the liver. Nat Immunol. (2013) 14:996-1006. doi: 10.1038/ni.2691

4. Bjorkstrom NK, Ljunggren HG, Michaelsson J. Emerging insights into natural killer cells in human peripheral tissues. Nat Rev Immunol. (2016) 16:310-20. doi: 10.1038/nri.2016.34

5. Gao B, Jeong WI, Tian, Z. Liver: an organ with predominant innate immunity. Hepatology. (2008) 47:729-36. doi: 10.1002/hep.22034

6. Vivier E, Raulet DH, Moretta A, Caligiuri MA, Zitvogel L, Lanier LL, et al. Innate or adaptive immunity? The example of natural killer cells. Science. (2011) 331:44-9. doi: 10.1126/science.1198687

7. Lanier LL. Up on the tightrope: natural killer cell activation and inhibition. Nat Immunol. (2008) 9:495-502. doi: 10.1038/ni1581

8. Ljunggren $\mathrm{HG}$, Karre $\mathrm{K}$. In search of the 'missing self': MHC molecules and NK cell recognition. Immunol Today. (1990) 11:237-44. doi: 10.1016/0167-5699(90)90097-S

9. Karre K. Natural killer cell recognition of missing self. Nat Immunol. (2008) 9:477-80. doi: 10.1038/ni0508-477

10. Long EO, Kim HS, Liu D, Peterson ME, Rajagopalan S. Controlling natural killer cell responses: integration of signals for activation and inhibition. Annu Rev Immunol. (2008) 31:227-58. doi: 10.1146/annurev-immunol-020711-075005

11. Shibuya K, Lanier LL, Phillips JH, Ochs HD, Shimizu K, Nakayama E, et al. Physical and functional association of LFA-1 with DNAM-1 adhesion molecule. Immunity. (1999) 11:615-23. doi: 10.1016/S1074-7613(00)80136-3

12. Cooper MA, Fehniger TA, Caligiuri MA. The biology of human natural killer-cell subsets. Trends Immunol. (2001) 22:633-40. doi: 10.1016/S1471-4906(01)02060-9

13. Marcenaro E, Notarangelo LD, Orange JS, Vivier E. Editorial: NK cell subsets in health and disease: new developments. Front Immunol. (2017) 8:1363. doi: 10.3389/fimmu.2017.01363

14. Scoville SD, Freud AG, Caligiuri MA. Modeling human natural killer cell development in the era of innate lymphoid cells. Front Immunol. (2017) 8:360. doi: 10.3389/fimmu.2017.00360

15. Fehniger TA, Cooper MA, Nuovo GJ, Cella M, Facchetti F, Colonna $\mathrm{M}$, et al. CD56bright natural killer cells are present in human lymph and their abilities to be tolerogenic toward foreign antigens while attacking viruses and tumors. This knowledge is key to understand and target those mechanisms participating in the onset of hepatic disorders.

\section{AUTHOR CONTRIBUTIONS}

All authors listed have made a substantial, direct and intellectual contribution to the work, and approved it for publication.

\section{FUNDING}

This work was supported by Associazione Italiana per la Ricerca sul Cancro (IG-14687 and IG 21567 to DM), Italian Ministry of Health (Bando Ricerca Finalizzata PE-2016-02363915) and Intramural Research Funding of Istituto Clinico Humanitas (to $\mathrm{DM})$. CDV is recipient of the post-doctoral fellowships from the Fondazione Umberto Veronesi (2017-1464 and 2018-1974). nodes and are activated by $\mathrm{T}$ cell-derived IL-2: a potential new link between adaptive and innate immunity. Blood. (2003) 101:30527. doi: 10.1182/blood-2002-09-2876

16. Ferlazzo G, Pack M, Thomas D, Paludan C, Schmid D, Strowig T, et al. Distinct roles of IL-12 and IL-15 in human natural killer cell activation by dendritic cells from secondary lymphoid organs. Proc Natl Acad Sci USA. (2004) 101:16606-11. doi: 10.1073/pnas.0407522101

17. Caligiuri MA, Human natural killer cells. Blood. (2008) 112:4619. doi: 10.1182/blood-2007-09-077438

18. Cichicki F, Schlums H, Theorell J, Tesi B, Miller JS, Ljunggren HG, et al. Diversification and functional specialization of human NK cell subsets. Curr Top Microbiol Immunol. (2016) 395:63-94. doi: 10.1007/82_ 2015_487

19. De Maria A, Bozzano F, Cantoni C, Moretta L. Revisiting human natural killer cell subset function revealed cytolytic CD56(dim)CD16+ NK cells as rapid producers of abundant IFN-gamma on activation. Proc Natl Acad Sci USA. (2011) 108:728-32. doi: 10.1073/pnas.1012356108

20. Mikulak J, Oriolo F, Zaghi E, Di Vito C, Mavilio D. Natural killer cells in HIV-1 infection and therapy. AIDS. (2017) 31:2317-30. doi: 10.1097/QAD.0000000000001645

21. Lugli E, Marcenaro E, Mavilio D. NK cell subset redistribution during the course of viral infections. Front Immunol. (2014) 5:390. doi: 10.3389/fimmu.2014.00390

22. Stabile H, Nisti P, Morrone S, Pagliara D, Bertaina A, Locatelli F, et al. Multifunctional human CD56 low CD16 low natural killer cells are the prominent subset in bone marrow of both healthy pediatric donors and leukemic patients. Haematologica. (2015) 100:48998. doi: 10.3324/haematol.2014.116053

23. Roberto A, Di Vito C, Zaghi E, Mazza MC, Capucetti A, Calvi M, et al. The early expansion of anergic NKG2A(pos)/CD56(dim)/CD16(neg) natural killer represents a therapeutic target in haploidentical hematopoietic stem cell transplantation. Haematologica. (2018) 103:1390-402. doi: 10.3324/haematol.2017.186619

24. Carrega P, Bonaccorsi I, Di Carlo E, Morandi B, Paul P, Rizzello $\mathrm{V}$, et al. CD56(bright)perforin(low) noncytotoxic human NK cells are abundant in both healthy and neoplastic solid tissues and recirculate to secondary lymphoid organs via afferent lymph. J Immunol. (2014) 192:380515. doi: 10.4049/jimmunol.1301889

25. Freud AG, Mundy-Bosse BL, Yu J, Caligiuri MA. The broad spectrum of human natural killer cell diversity. Immunity. (2017) 47:820-33. doi: 10.1016/j.immuni.2017.10.008

26. Peng H, Tian Z. Diversity of tissue-resident NK cells. Semin Immunol. (2017) 31:3-10. doi: 10.1016/j.smim.2017.07.006 
27. Peng H, Jiang X, Chen Y, Sojka DK, Wei H, Gao X, et al. Liver-resident NK cells confer adaptive immunity in skin-contact inflammation. J Clin Invest. (2013) 123:1444-56. doi: 10.1172/JCI66381

28. Marquardt N, Beziat V, Nystrom S, Hengst J, Ivarsson MA, Kekalainen E, et al. Cutting edge: identification and characterization of human intrahepatic CD49a+ NK cells. J Immunol. (2015) 194:2467-71. doi: 10.4049/jimmunol.1402756

29. Constantinides MG, McDonald BD, Verhoef PA, Bendelac A. A committed precursor to innate lymphoid cells. Nature. (2014) 508:397-401. doi: 10.1038/nature13047

30. Klose SN, Flach M, Mohle L, Rogell L, Hoyler T, Ebert K, et al. Differentiation of type 1 ILCs from a common progenitor to all helper-like innate lymphoid cell lineages. Cell. (2014) 157:340-56. doi: 10.1016/j.cell.2014.03.030

31. Sojka DK, Plougastel-Douglas B, Yang L, Pak-Wittel MA, Artyomov MN, Ivanova $\mathrm{Y}$, et al. Tissue-resident natural killer (NK) cells are cell lineages distinct from thymic and conventional splenic NK cells. Elife. (2014) 3:e01659. doi: 10.7554/eLife.01659

32. Daussy C, Faure F, Mayol K, Viel S, Gasteiger G, Charrier E, et al. Tbet and Eomes instruct the development of two distinct natural killer cell lineages in the liver and in the bone marrow. J Exp Med. (2014) 211:56377. doi: 10.1084 /jem. 20131560

33. Mackay LK, Minnich M, Kragten NA, Liao Y, Nota B, Seillet C, et al. Hobit and Blimpl instruct a universal transcriptional program of tissue residency in lymphocytes. Science. (2016) 352:459-63. doi: 10.1126/science.aad2035

34. Zhang LH, Shin JH, Haggadone MD, Sunwoo JB. The aryl hydrocarbon receptor is required for the maintenance of liver-resident natural killer cells. J Exp Med. (2016) 213:2249-57. doi: 10.1084/jem.20151998

35. Luo DZ, Vermijlen D, Ahishali B, Triantis V, Plakoutsi G, Braet F, et al. On the cell biology of pit cells, the liver-specific NK cells. World J Gastroenterol. (2000) 6:1-11. doi: 10.3748/wjg.v6.i1.1

36. Harmon C, Robinson MW, Fahey R, Whelan S, Houlihan DD, Geoghegan J, et al. Tissue-resident Eomes(hi) T-bet(lo) CD56(bright) NK cells with reduced proinflammatory potential are enriched in the adult human liver. Eur J Immunol. (2016) 46:2111-20. doi: 10.1002/eji.201646559

37. Lunemann S, Martrus G, Goebels H, Kautz T, Langeneckert A, Salzberger W, et al. Hobit expression by a subset of human liver-resident CD56(bright) Natural Killer cells. Sci Rep. (2017) 7:6676. doi: 10.1038/s41598-017-0 6011-7

38. Luo D, Vanderkerken K, Bouwens L, Kuppen PJ, Baekeland M, Seynaeve $\mathrm{C}$, et al. The role of adhesion molecules in the recruitment of hepatic natural killer cells (pit cells) in rat liver. Hepatology. (1996) 24:147580. doi: 10.1002/hep.510240629

39. Mellergard J, Edstrom M, Jenmalm MC, Dahle C, Vrethem M, Ernerudh J. Increased B cell and cytotoxic NK cell proportions and increased T cell responsiveness in blood of natalizumab-treated multiple sclerosis patients. PLoS ONE. (2013) 8:e81685. doi: 10.1371/journal.pone.0081685

40. Reeves RK, Li H, Jost S, Blass E, Li H, Schafer JL, et al. Antigenspecific NK cell memory in rhesus macaques. Nat Immunol. (2015) 16:92732. doi: 10.1038/ni.3227

41. Hydes T, Abuhilal M, Armstrong T, Primrose J, Takhar A, Khakoo S. Natural killer cell maturation markers in the human liver and expansion of an NKG2C+KIR+ population. Lancet. (2015) 385(Suppl. 1):S45. doi: 10.1016/S0140-6736(15)60360-9

42. Ishiyama K, Ohdan H, Ohira M, Mitsuta H, Arihiro K, Asahara T. Difference in cytotoxicity against hepatocellular carcinoma between liver and periphery natural killer cells in humans. Hepatology. (2006) 43:36272. doi: 10.1002/hep.21035

43. Nakatani K, Kaneda K, Seki S, Nakajima Y. Pit cells as liver-associated natural killer cells: morphology and function. Med Electron Microsc. (2004) 37:29-36. doi: 10.1007/s00795-003-0229-9

44. Doherty DG, Norris S, Madrigal-Estebas L, McEntee G, Traynor O, Hegarty JE, et al. The human liver contains multiple populations of NK cells, T cells, and CD3+CD56+ natural T cells with distinct cytotoxic activities and Th1, Th2, and Th0 cytokine secretion patterns. J Immunol. (1999) 163:2314-21.

45. Hudspeth K, Donadon M, Cimino M, Pontarini E, Tentorio P, Preti M, et al. Human liver-resident CD56(bright)/CD16(neg) NK cells are retained within hepatic sinusoids via the engagement of CCR5 and CXCR6 pathways. J Autoimmun. (2016) 66:40-50. doi: 10.1016/j.jaut.2015.08.011
46. Stegmann KA, Robertson F, Hansi N, Gill U, Pallant C, Christophides T, et al. CXCR6 marks a novel subset of T-bet(lo)Eomes(hi) natural killer cells residing in human liver. Sci Rep. (2016) 6:26157. doi: 10.1038/srep26157

47. Lalor PF, Edwards S, McNab G, Salmi M, Jalkanen S, Adams DH. Vascular adhesion protein-1 mediates adhesion and transmigration of lymphocytes on human hepatic endothelial cells. J Immunol. (2002) 169:98392. doi: 10.4049/jimmunol.169.2.983

48. Mikulak J, Di Vito C, Zaghi E, Mavilio D. Host immune responses in HIV-1 infection: the emerging pathogenic role of siglecs and their clinical correlates. Front Immunol. (2017) 8:314. doi: 10.3389/fimmu.2017.00314

49. Cuff AO, Robertson FP, Stegmann KA, Pallett LJ, Maini MK, Davidson $\mathrm{BR}$, et al. Eomeshi NK cells in human liver are long-lived and do not recirculate but can be replenished from the circulation. J Immunol. (2016) 197:4283-91. doi: 10.4049/jimmunol.1601424

50. Plavina T, Muralidharan KK, Kuesters G, Mikol D, Evans K, Subramanyam $M$, et al. Reversibility of the effects of natalizumab on peripheral immune cell dynamics in MS patients. Neurology. (2017) 89:158493. doi: 10.1212/WNL.0000000000004485

51. Majewska-Szczepanik M, Paust S, von Andrian UH, Askenase PW, Szczepanik M. Natural killer cell-mediated contact sensitivity develops rapidly and depends on interferon-alpha, interferon-gamma and interleukin-12. Immunology. (2013) 140:98-110. doi: 10.1111/imm.12120

52. O’Leary JG, Goodarzi M, Drayton DL, von Andrian UH. T cell- and B cell-independent adaptive immunity mediated by natural killer cells. Nat Immunol. (2006) 7:507-16. doi: 10.1038/ni1332

53. Paust S, Gill HS, Wang BZ, Flynn MP, Moseman EA, Senman B, et al. Critical role for the chemokine receptor CXCR6 in NK cell-mediated antigenspecific memory of haptens and viruses. Nat Immunol. (2010) 11:112735. doi: 10.1038/ni.1953

54. Peng H, Tian Z. Natural killer cell memory: progress and implications. Front Immunol. (2017) 8:1143. doi: 10.3389/fimmu.2017.01143

55. Lopez-Verges S, Milush JM, Schwartz BS, Pando MJ, Jarjoura J, York VA, et al. Expansion of a unique CD57(+)NKG2Chi natural killer cell subset during acute human cytomegalovirus infection. Proc Natl Acad Sci USA. (2011) 108:14725-32. doi: 10.1073/pnas.1110900108

56. Li N, Puga Yung GL, Pradier A, Toso C, Giostra E, Morard I, et al. NK cell isolation from liver biopsies: phenotypic and functional analysis of low cell numbers by flow cytometry. Front Immunol. (2013) 4:61. doi: 10.3389/fimmu.2013.00061

57. Tang L, Peng H, Zhou J, Chen Y, Wei H, Sun R, et al. Differential phenotypic and functional properties of liver-resident NK cells and mucosal ILC1s. $J$ Autoimmun. (2016) 67:29-35. doi: 10.1016/j.jaut.2015.09.004

58. Cunningham EC, Sharland AF, Bishop GA. Liver transplant tolerance and its application to the clinic: can we exploit the high dose effect? Clin Dev Immunol. (2013) 2013:419692. doi: 10.1155/2013/419692

59. Lassen MG, Lukens JR, Dolina JS, Brown MG, Hahn YS. Intrahepatic IL-10 maintains NKG2A+Ly49- liver NK cells in a functionally hyporesponsive state. J Immunol. (2010) 184:2693-701. doi: 10.4049/jimmunol.0901362

60. Chen Y, Sun R, Jiang W, Wei H, Tian Z. Liver-specific HBsAg transgenic mice are over-sensitive to Poly(I:C)-induced liver injury in NK cell- and IFN-gamma-dependent manner. J Hepatol. (2007) 47:18390. doi: 10.1016/j.jhep.2007.02.020

61. Tu Z, Bozorgzadeh A, Pierce RH, Kurtis J, Crispe IN, Orloff MS. TLRdependent cross talk between human Kupffer cells and NK cells. J Exp Med. (2008) 205:233-44. doi: 10.1084/jem.20072195

62. Jinushi M, Takehara T, Tatsumi T, Yamaguchi S, Sakamori R, Hiramatsu N, et al. Natural killer cell and hepatic cell interaction via NKG2A leads to dendritic cell-mediated induction of CD4 CD25T cells with PD-1-dependent regulatory activities. Immunology. (2007) 120:73-82. doi: 10.1111/j.1365-2567.2006.02479.x

63. Jinushi M, Takehara T, Tatsumi T, Kanto T, Miyagi T, Suzuki T, et al. Negative regulation of NK cell activities by inhibitory receptor CD94/NKG2A leads to altered NK cell-induced modulation of dendritic cell functions in chronic hepatitis C virus infection. J Immunol. (2004) 173:607281. doi: 10.4049/jimmunol.173.10.6072

64. Chong WP, Zhou J, Law HK, Tu W, Lau YL. Natural killer cells become tolerogenic after interaction with apoptotic cells. Eur J Immunol. (2010) 40:1718-27. doi: 10.1002/eji.200939768 
65. Tosello-Trampont A, Surette FA, Ewald SE, Hahn YS. Immunoregulatory role of NK cells in tissue inflammation and regeneration. Front Immunol. (2017) 8:301. doi: 10.3389/fimmu.2017.00301

66. Li N, Hua J. Immune cells in liver regeneration. Oncotarget. (2017) 8:362839. doi: 10.18632/oncotarget.12275

67. Cosgrove BD, Cheng C, Pritchard JR, Stolz DB, Lauffenburger DA, Griffith LG. An inducible autocrine cascade regulates rat hepatocyte proliferation and apoptosis responses to tumor necrosis factor-alpha. Hepatology. (2008) 48:276-88. doi: 10.1002/hep.22335

68. Bi J, Zheng X, Chen Y, Wei H, Sun R, Tian Z. TIGIT safeguards liver regeneration through regulating natural killer cell-hepatocyte crosstalk. Hepatology. (2014) 60:1389-98. doi: 10.1002/hep.27245

69. Sun R, Gao B. Negative regulation of liver regeneration by innate immunity (natural killer cells/interferon-gamma). Gastroenterology. (2004) 127:152539. doi: 10.1053/j.gastro.2004.08.055

70. Wang J, Sun R, Wei H, Dong Z, Gao B, Tian Z. Poly I:C prevents T cell-mediated hepatitis via an NK-dependent mechanism. J Hepatol. (2006) 44:446-54. doi: 10.1016/j.jhep.2005.08.015

71. Robinson MW, Harmon C, O’Farrelly C. Liver immunology and its role in inflammation and homeostasis. Cell Mol Immunol. (2016) 13:26776. doi: $10.1038 / \mathrm{cmi} .2016 .3$

72. Oo YH, Hubscher SG, Adams DH. Autoimmune hepatitis: new paradigms in the pathogenesis, diagnosis, and management. Hepatol Int. (2010) 4:47593. doi: 10.1007/s12072-010-9183-5

73. Strassburg CP, Obermayer-Straub P, Manns MP. Autoimmunity in liver diseases. Clin Rev Allergy Immunol. (2000) 18:12739. doi: 10.1385/CRIAI:18:2:127

74. Littera R, Chessa L, Onali S, Figorilli F, Lai S, Secci L, et al. Exploring the role of killer cell immunoglobulin-like receptors and their HLA class I ligands in autoimmune hepatitis. PLoS ONE. (2016) 11:e0146086. doi: 10.1371/journal.pone.0146086

75. Gershwin ME, Ansari AA, Mackay IR, Nakanuma Y, Nishio A, Rowley MJ, et al. Primary biliary cirrhosis: an orchestrated immune response against epithelial cells. Immunol Rev. (2000) 174:210-25. doi: 10.1034/j.1600-0528.2002.017402.x

76. Lleo A, Bowlus CL, Yang GX, Invernizzi P, Podda M, Van de Water J, et al. Biliary apotopes and anti-mitochondrial antibodies activate innate immune responses in primary biliary cirrhosis. Hepatology. (2010) 52:98798. doi: 10.1002/hep.23783

77. Chuang YH, Lian ZX, Tsuneyama K, Chiang BL, Ansari AA, Coppel RL, et al. Increased killing activity and decreased cytokine production in NK cells in patients with primary biliary cirrhosis. J Autoimmun. (2006) 26:23240. doi: 10.1016/j.jaut.2006.04.001

78. Liang Y, Yang Z, Li C, Zhu Y, Zhang L, Zhong R. Characterisation of TNF-related apoptosis-inducing ligand in peripheral blood in patients with primary biliary cirrhosis. Clin Exp Med. (2008) 8:1-7. doi: 10.1007/s10238-008-0149-Z

79. Takeda K, Kojima Y, Ikejima K, Harada K, Yamashina S, Okumura $\mathrm{K}$, et al. Death receptor 5 mediated-apoptosis contributes to cholestatic liver disease. Proc Natl Acad Sci USA. (2008) 105:10895-900. doi: 10.1073/pnas.0802702105

80. Shimoda S, Hisamoto S, Harada K, Iwasaka S, Chong Y, Nakamura M, et al. Natural killer cells regulate $\mathrm{T}$ cell immune responses in primary biliary cirrhosis. Hepatology. (2015) 62:1817-27. doi: 10.1002/hep.28122

81. Karlsen TH, Boberg KM, Olsson M, Sun JY, Senitzer D, Bergquist A, et al. Particular genetic variants of ligands for natural killer cell receptors may contribute to the HLA associated risk of primary sclerosing cholangitis. $J$ Hepatol. (2007) 46:899-906. doi: 10.1016/j.jhep.2007.01.032

82. Hashimoto E, Lindor KD, Homburger HA, Dickson ER, Czaja AJ, Wiesner $\mathrm{RH}$, et al. Immunohistochemical characterization of hepatic lymphocytes in primary biliary cirrhosis in comparison with primary sclerosing cholangitis and autoimmune chronic active hepatitis. Mayo Clin Proc. (1993) 68:104955. doi: 10.1016/S0025-6196(12)60897-0

83. Hata K, Van Thiel DH, Herberman RB, Whiteside TL. Phenotypic and functional characteristics of lymphocytes isolated from liver biopsy specimens from patients with active liver disease. Hepatology. (1992) 15:81623. doi: 10.1002/hep.1840150512
84. Bo X, Broome U, Remberger M, Sumitran-Holgersson S. Tumour necrosis factor alpha impairs function of liver derived $\mathrm{T}$ lymphocytes and natural killer cells in patients with primary sclerosing cholangitis. Gut. (2001) 49:131-41. doi: 10.1136/gut.49.1.131

85. Siegel RL, Miller KD, Jemal A. Cancer statistics, 2017. CA Cancer J Clin. (2017) 67:7-30. doi: 10.3322/caac.21387

86. Wallace MC, Preen D, Jeffrey GP, Adams LA. The evolving epidemiology of hepatocellular carcinoma: a global perspective. Expert Rev Gastroenterol Hepatol. (2015) 9:765-79. doi: 10.1586/17474124.2015.10 28363

87. Tomlinson JS, Jarnagin WR, DeMatteo RP, Fong Y, Kornprat P, Gonen M, et al. Actual 10-year survival after resection of colorectal liver metastases defines cure. J Clin Oncol. (2007) 25:4575-80. doi: 10.1200/JCO.2007. 11.0833

88. Cantoni C, Huergo-Zapico L, Parodi M, Pedrazzi M, Mingari MC, Moretta A, et al. NK cells, tumor cell transition, and tumor progression in solid malignancies: new hints for NK-based immunotherapy? I Immunol Res. (2016) 2016:4684268. doi: 10.1155/2016/4684268

89. Chiossone L, Vienne M, Kerdiles YM, Vivier E. Natural killer cell immunotherapies against cancer: checkpoint inhibitors and more. Semin Immunol. (2017) 31:55-63. doi: 10.1016/j.smim.2017. 08.003

90. Chew V, Tow C, Teo M, Wong HL, Chan J, Gehring A, et al. Inflammatory tumour microenvironment is associated with superior survival in hepatocellular carcinoma patients. J Hepatol. (2010) 52:3709. doi: 10.1016/j.jhep.2009.07.013

91. Chew V, Chen J, Lee D, Loh E, Lee J, Lim KH, et al. Chemokine-driven lymphocyte infiltration: an early intratumoural event determining longterm survival in resectable hepatocellular carcinoma. Gut. (2012) 61:42738. doi: 10.1136/gutjnl-2011-300509

92. Cai L, Zhang Z, Zhou L, Wang H, Fu J, Zhang S, et al. Functional impairment in circulating and intrahepatic NK cells and relative mechanism in hepatocellular carcinoma patients. Clin Immunol. (2008) 129:42837. doi: 10.1016/j.clim.2008.08.012

93. Donadon M, Hudspeth K, Cimino M, Di Tommaso L, Preti M, Tentorio $\mathrm{P}$, et al. Increased infiltration of natural killer and t cells in colorectal liver metastases improves patient overall survival. J Gastrointest Surg. (2017) 21:1226-36. doi: 10.1007/s11605-017-3446-6

94. Zhang QF, Yin WW, Xia Y, Yi YY, He QF, Wang X, et al. Liver-infiltrating CD11b(-)CD27(-) NK subsets account for NK-cell dysfunction in patients with hepatocellular carcinoma and are associated with tumor progression. Cell Mol Immunol. (2017) 14:819-29. doi: 10.1038/cmi.2016.28

95. Abdelrahman MM, Fawzy IO, Bassiouni AA, Gomaa AI, Esmat G, Waked I, et al. Enhancing NK cell cytotoxicity by miR-182 in hepatocellular carcinoma. Hum Immunol. (2016) 77:667-73. doi: 10.1016/j.humimm.2016.04.020

96. Lasfar A, de laTorre A, Abushahba W, Cohen-Solal KA, Castaneda I, Yuan $\mathrm{Y}$, et al. Concerted action of IFN-alpha and IFN-lambda induces local NK cell immunity and halts cancer growth. Oncotarget. (2016) 7:4925967. doi: 10.18632/oncotarget.10272

97. Fathy A, Eldin MM, Metwally L, Eida M, Abdel-Rehim M. Diminished absolute counts of CD56dim and CD56bright natural killer cells in peripheral blood from Egyptian patients with hepatocellular carcinoma. Egypt $J$ Immunol. (2009) 16:17-25.

98. Wu Y, Kuang DM, Pan WD, Wan YL, Lao XM, Wang D, et al. Monocyte/macrophage-elicited natural killer cell dysfunction in hepatocellular carcinoma is mediated by CD48/2B4 interactions. Hepatology. (2013) 57:1107-16. doi: 10.1002/hep.26192

99. Huang J, Cai MY, Wei DP. HLA class I expression in primary hepatocellular carcinoma. World J Gastroenterol. (2002) 8:654-7. doi: 10.3748/wjg.v8.i4.654

100. Kudo M. Immuno-oncology in hepatocellular carcinoma: 2017 update. Oncology. (2017) 93(Suppl. 1):147-59.

101. Sun $\mathrm{C}, \mathrm{Xu} J$, Huang $\mathrm{Q}$, Huang $\mathrm{M}$, Wen $\mathrm{H}$, Zhang $\mathrm{C}$, et al. High NKG2A expression contributes to NK cell exhaustion and predicts a poor prognosis of patients with liver cancer. Oncoimmunology. (2017) 6:e1264562. doi: 10.1080/2162402X.2016. 1264562 
102. Liu Y, Cheng Y, Xu Y, Wang Z, Du X, Li C, et al. Increased expression of programmed cell death protein 1 on NK cells inhibits NK-cell-mediated antitumor function and indicates poor prognosis in digestive cancers. Oncogene. (2017) 36:6143-53. doi: 10.1038/onc.2017.209

103. Mantovani S, Oliviero B, Lombardi A, Varchetta S, Mele D, Sangiovanni A, et al. Deficient natural killer cell NKp30-mediated function and altered NCR3 splice variants in hepatocellular carcinoma. Hepatology. (2018) 69:1165-79. doi: 10.1002/hep.30235

104. Coulouarn C, Factor VM, Conner EA, Thorgeirsson SS. Genomic modeling of tumor onset and progression in a mouse model of aggressive human liver cancer. Carcinogenesis. (2011) 32:1434-40. doi: 10.1093/carcin/bgr133

105. Hoechst B, Voigtlaender T, Ormandy L, Gamrekelashvili J, Zhao F, Wedemeyer $\mathrm{H}$, et al. Myeloid derived suppressor cells inhibit natural killer cells in patients with hepatocellular carcinoma via the NKp30 receptor. Hepatology. (2009) 50:799-807. doi: 10.1002/hep.23054

106. Li T, Yang Y, Hua X, Wang G, Liu W, Jia C, Tai Y, Zhang Q, Chen G. Hepatocellular carcinoma-associated fibroblasts trigger NK cell dysfunction via PGE2 and IDO. Cancer Lett. (2012) 318:15461. doi: 10.1016/j.canlet.2011.12.020

107. Shen Y, Wei Y, Wang Z, Jing Y, He H, Yuan J, et al. TGF-beta regulates hepatocellular carcinoma progression by inducing Treg cell polarization. Cell Physiol Biochem. (2015) 35:1623-32. doi: 10.1159/000373976

108. Molgora M, Bonavita E, Ponzetta A, Riva F, Barbagallo M, Jaillon S, et al. IL1 R8 is a checkpoint in NK cells regulating anti-tumour and anti-viral activity. Nature. (2017) 551:110-4. doi: 10.1038/nature24293

109. Jung IH, Kim DH, Yoo DK, Baek SY, Jeong SH, Jung DE, et al. In vivo study of natural killer (NK) cell cytotoxicity against cholangiocarcinoma in a nude mouse model. In Vivo. (2018) 32:771-81. doi: 10.21873/invivo.11307

110. Liu P, Chen L, Zhang H. Natural killer cells in liver disease and hepatocellular carcinoma and the NK cell-based immunotherapy. J Immunol Res. (2018) 2018:1206737. doi: 10.1155/2018/1206737

111. Amadei B, Urbani S, Cazaly A, Fisicaro P, Zerbini A, Ahmed P, et al. Activation of natural killer cells during acute infection with hepatitis $\mathrm{C}$ virus. Gastroenterology. (2010) 138:1536-45. doi: 10.1053/j.gastro.2010.01.006

112. Gupta N, Arthos J, Khazanie P, Steenbeke TD, Censoplano NM, Chung EA, et al. Targeted lysis of HIV-infected cells by natural killer cells armed and triggered by a recombinant immunoglobulin fusion protein: implications for immunotherapy. Virology. (2005) 332:491-7. doi: 10.1016/j.virol.2004.12.018

113. Castagna L, Mavilio D. Re-discovering NK cell allo-reactivity in the therapy of solid tumors. J Immunother Cancer. (2016) 4:54. doi: 10.1186/s40425-016-0159-4

114. de Groen RA, Groothuismink MA, van Oord G, Kootstra NA, Janssen LA, Prins M, et al. NK cells in self-limited HCV infection exhibit a more extensively differentiated, but not memory-like, repertoire. J Viral Hepat. (2017) 24:917-26. doi: 10.1111/jvh.12716

115. Webster GJ, Reignat S, Maini MK, Whalley SA, Ogg GS, King A, et al. Incubation phase of acute hepatitis B in man: dynamic of cellular immune mechanisms. Hepatology. (2000) 32:1117-24. doi: 10.1053/jhep.2000.19324

116. Fisicaro P, Valdatta C, Boni C, Massari M, Mori C, Zerbini A, et al. Early kinetics of innate and adaptive immune responses during hepatitis $\mathrm{B}$ virus infection. Gut. (2009) 58:974-82. doi: 10.1136/gut.2008.163600

117. Li J, Han Y, Jin K, Wan Y, Wang S, Liu B, et al. Dynamic changes of cytotoxic T lymphocytes (CTLs), natural killer (NK) cells, and natural killer $\mathrm{T}$ (NKT) cells in patients with acute hepatitis B infection. Virol J. (2011) 8:199. doi: 10.1186/1743-422X-8-199

118. Zhao J, Li Y, Jin L, Zhang S, Fan R, Sun Y, et al. Natural killer cells are characterized by the concomitantly increased interferon-gamma and cytotoxicity in acute resolved hepatitis B patients. PLoS ONE. (2012) 7:e49135. doi: 10.1371/journal.pone.0049135

119. Billerbeck E, Wolfisberg R, Fahnoe U, Xiao JW, Quirk C, Luna JM, et al. Mouse models of acute and chronic hepacivirus infection. Science. (2017) 357:204-8. doi: 10.1126/science.aal1962

120. Fu Q, Yan S, Wang L, Duan X, Wang L, Wang Y, et al. Hepatic NK cell-mediated hypersensitivity to ConA-induced liver injury in mouse liver expressing hepatitis C virus polyprotein. Oncotarget. (2017) 8:5217892. doi: 10.18632/oncotarget.11052

121. Guy CS, Mulrooney-Cousins PM, Churchill ND, Michalak TI. Intrahepatic expression of genes affiliated with innate and adaptive immune responses immediately after invasion and during acute infection with woodchuck hepadnavirus. J Virol. (2008) 82:8579-91. doi: 10.1128/JVI.01022-08

122. Oliviero B, Varchetta S, Paudice E, Michelone G, Zaramella M, Mavilio D, et al. Natural killer cell functional dichotomy in chronic hepatitis B and chronic hepatitis C virus infections. Gastroenterology. (2009) 137:1151-60, 1160e1-7. doi: 10.1053/j.gastro.2009.05.047

123. Dessouki O, Kamiya Y, Nagahama H, Tanaka M, Suzu S, Sasaki Y, et al. Chronic hepatitis $\mathrm{C}$ viral infection reduces NK cell frequency and suppresses cytokine secretion: reversion by anti-viral treatment. Biochem Biophys Res Commun. (2010) 393:331-7. doi: 10.1016/j.bbrc.2010.02.008

124. Yang Y, Han Q, Hou Z, Zhang C, Tian Z, Zhang J. Exosomes mediate hepatitis $\mathrm{B}$ virus (HBV) transmission and NK-cell dysfunction. Cell Mol Immunol. (2017) 14:465-75. doi: 10.1038/cmi.2016.24

125. Tjwa ET, van Oord GW, Hegmans JP, Janssen HL, Woltman AM. Viral load reduction improves activation and function of natural killer cells in patients with chronic hepatitis. J Hepatol B. (2011) 54:20918. doi: 10.1016/j.jhep.2010.07.009

126. Dunn C, Brunetto M, Reynolds G, Christophides T, Kennedy PT, Lampertico $\mathrm{P}$, et al. Cytokines induced during chronic hepatitis $\mathrm{B}$ virus infection promote a pathway for NK cell-mediated liver damage. J Exp Med. (2007) 204:66780. doi: $10.1084 /$ jem.20061287

127. Peppa D, Micco L, Javaid A, Kennedy PT, Schurich A, Dunn C, et al. Blockade of immunosuppressive cytokines restores NK cell antiviral function in chronic hepatitis B virus infection. PLoS Pathog. (2010) 6:e1001227. doi: 10.1371/journal.ppat.1001227

128. Maini MK, Boni C, Lee CK, Larrubia JR, Reignat S, Ogg GS, et al. The role of virus-specific $\mathrm{CD} 8(+)$ cells in liver damage and viral control during persistent hepatitis B virus infection. J Exp Med. (2000) 191:1269_ 80. doi: 10.1084/jem.191.8.1269

129. Boni C, Fisicaro P, Valdatta C, Amadei B, Di Vincenzo P, Giuberti $\mathrm{T}$, et al. Characterization of hepatitis $\mathrm{B}$ virus (HBV)-specific T-cell dysfunction in chronic HBV infection. J Virol. (2007) 81:4215-25. doi: 10.1128/JVI.02844-06

130. Peppa D, Gill US, Reynolds G, Easom NJ, Pallett LJ, Schurich A, et al. Upregulation of a death receptor renders antiviral $\mathrm{T}$ cells susceptible to NK cell-mediated deletion. J Exp Med. (2013) 210:99-114. doi: 10.1084/jem.201 21172

131. Sun C, Fu B, Gao Y, Liao X, Sun R, Tian Z, et al. TGF-beta1 down-regulation of NKG2D/DAP10 and 2B4/SAP expression on human NK cells contributes to HBV persistence. PLoS Pathog. (2012) 8:e1002594. doi: 10.1371/journal.ppat.1002594

132. Subleski JJ, Hall VL, Back TC, Ortaldo JR, Wiltrout RH. Enhanced antitumor response by divergent modulation of natural killer and natural killer $\mathrm{T}$ cells in the liver. Cancer Res. (2006) 66:1100512. doi: 10.1158/0008-5472.CAN-06-0811

133. Rockey DC, Current and future anti-fibrotic therapies for chronic liver disease. Clin Liver Dis. (2008) 12:939-62. doi: 10.1016/j.cld.2008. 07.011

134. Burns LJ, Weisdorf DJ, DeFor TE, Vesole DH, Repka TL, Blazar BR, et al. IL-2-based immunotherapy after autologous transplantation for lymphoma and breast cancer induces immune activation and cytokine release: a phase I/II trial. Bone Marrow Transplant. (2003) 32:17786. doi: $10.1038 /$ sj.bmt.1704086

135. Pillet $\mathrm{AH}$, Theze J, Rose T. Interleukin (IL)-2 and IL-15 have different effects on human natural killer lymphocytes. Hum Immunol. (2011) 72:10137. doi: 10.1016/j.humimm.2011.07.311

136. Easom JW, Stegmann KA, Swadling L, Pallett LJ, Burton AR, Odera $\mathrm{D}$, et al. IL-15 overcomes hepatocellular carcinoma-induced NK cell dysfunction. Front Immunol. (2018) 9:1009. doi: 10.3389/fimmu.2018. 01009

137. Thaysen-Andersen M, Chertova E, Bergamaschi C, Moh ES, Chertov O, Roser J, et al. Recombinant human heterodimeric IL-15 complex displays extensive and reproducible $\mathrm{N}$ - and O-linked glycosylation. Glycoconj J. (2016) 33:417-33. doi: 10.1007/s10719-015-9627-1

138. Rosario M, Liu B, Kong L, Collins LI, Schneider SE, Chen X, et al. The IL-15-Based ALT-803 complex enhances FcgammaRIIIa-triggered NK cell responses and in vivo clearance of B cell lymphomas. Clin Cancer Res. (2016) 22:596-608. doi: 10.1158/1078-0432.CCR-15-1419 
139. Levin AM, Bates DL, Ring AM, Krieg C, Lin JT, Su L, et al. Exploiting a natural conformational switch to engineer an interleukin-2 'superkine'. Nature. (2012) 484:529-33. doi: 10.1038/ nature 10975

140. Benson DM Jr, Cohen AD, Jagannath S, Munshi NC, Spitzer G, Hofmeister CC, et al. A phase I trial of the anti-KIR antibody IPH2101 and lenalidomide in patients with relapsed/refractory multiple myeloma. Clin Cancer Res. (2015) 21:4055-61. doi: 10.1158/1078-0432.CCR-15-0304

141. Rey J, Fauriat C, Kochbati E, Orlanducci F, Charbonnier A, D'Incan E, et al. Kinetics of cytotoxic lymphocytes reconstitution after induction chemotherapy in elderly AML patients reveals progressive recovery of normal phenotypic and functional features in NK cells. Front Immunol. (2017) 8:64. doi: 10.3389/fimmu.2017.00064

142. Chabannon C, Mfarrej B, Guia S, Ugolini S, Devillier R, Blaise D, et al. Manufacturing natural killer cells as medicinal products. Front Immunol. (2016) 7:504. doi: 10.3389/fimmu.2016.00504

143. Zaghi E, Calvi M, Marcenaro E, Mavilio D, Di Vito C. Targeting NKG2A to elucidate natural killer cell ontogenesis and to develop novel immune-therapeutic strategies in cancer therapy. J Leukoc Biol. (2019). doi: 10.1002/JLB.MR0718-300R

144. Andre P, Denis C, Soulas C, Bourbon-Caillet C, Lopez J, Arnoux T, et al. Anti-NKG2A mAb is a checkpoint inhibitor that promotes anti-tumor immunity by unleashing both T and NK cells. Cell. (2018) 175:1731-43 e13. doi: 10.1016/j.cell.2018.10.014

145. Della Chiesa M, Pesce S, Muccio L, Carlomagno S, Sivori S, Moretta A, et al. Features of memory-like and PD-1(+) human NK cell subsets. Front Immunol. (2016) 7:351. doi: 10.3389/fimmu.2016.00351

146. Ruggeri L, Capanni M, Urbani E, Perruccio K, Shlomchik WD, Tosti A, et al. Effectiveness of donor natural killer cell alloreactivity in mismatched hematopoietic transplants. Science. (2002) 295:2097-100. doi: 10.1126/science. 1068440

147. Locatelli F, Pende D, Mingari MC, Bertaina A, Falco M, Moretta A, et al. Cellular and molecular basis of haploidentical hematopoietic stem cell transplantation in the successful treatment of high-risk leukemias: role of alloreactive NK cells. Front Immunol. (2013) 4:15. doi: 10.3389/fimmu.2013.00015
148. Curti A, Ruggeri L, D'Addio A, Bontadini A, Dan E, Motta MR, et al. Successful transfer of alloreactive haploidentical KIR ligand-mismatched natural killer cells after infusion in elderly high risk acute myeloid leukemia patients. Blood. (2011) 118:3273-9. doi: 10.1182/blood-2011-01-329508

149. Bachanova V, Burns LJ, McKenna DH, Curtsinger J, PanoskaltsisMortari A, Lindgren BR, et al. Allogeneic natural killer cells for refractory lymphoma. Cancer Immunol Immunother. (2010) 59:173944. doi: 10.1007/s00262-010-0896-z

150. Iliopoulou EG, Kountourakis P, Karamouzis MV, Doufexis D, Ardavanis A, Baxevanis $\mathrm{CN}$, et al. A phase I trial of adoptive transfer of allogeneic natural killer cells in patients with advanced non-small cell lung cancer. Cancer Immunol Immunother. (2010) 59:1781-9. doi: 10.1007/s00262-0100904-3

151. Veluchamy JP, Kok N, van der Vliet HJ, Verheul MW, de Gruijl TD, Spanholtz J. The rise of allogeneic natural killer cells as a platform for cancer immunotherapy: recent innovations and future developments. Front Immunol. (2017) 8:631. doi: 10.3389/fimmu.2017.00631

152. Felices M, Lenvik TR, Davis ZB, Miller JS, Vallera DA. Generation of BiKEs and TriKEs to improve NK cell-mediated targeting of tumor cells. Methods Mol Biol. (2016) 1441:333-46. doi: 10.1007/978-1-49393684-7_28

153. Daher M, Rezvani K. Next generation natural killer cells for cancer immunotherapy: the promise of genetic engineering. Curr Opin Immunol. (2018) 51:146-53. doi: 10.1016/j.coi.2018.03.013

Conflict of Interest Statement: The authors declare that the research was conducted in the absence of any commercial or financial relationships that could be construed as a potential conflict of interest.

Copyright (c) 2019 Mikulak, Bruni, Oriolo, Di Vito and Mavilio. This is an openaccess article distributed under the terms of the Creative Commons Attribution License (CC BY). The use, distribution or reproduction in other forums is permitted, provided the original author(s) and the copyright owner(s) are credited and that the original publication in this journal is cited, in accordance with accepted academic practice. No use, distribution or reproduction is permitted which does not comply with these terms. 